\title{
Translation, cross-cultural adaptation and validation of the ABILHAND-Kids for the Brazilian Portuguese
}

\author{
Tradução, adaptação cultural e validação do ABILHAND-Kids para o português brasileiro \\ Traducción, adaptación cultural y validación del ABILHAND-Kids para el portugués \\ brasileño
}

\author{
Danilo Harudy Kamonseki', Luísa Cedin², Anile Ferraz Clemente', Beatriz de Oliveira Peixoto³, \\ Antonio Roberto Zamunér ${ }^{4}$
}

\begin{abstract}
I This study aimed to translate, to adapt cross-culturally and to validate the ABILHAND-Kids for the Brazilian Portuguese. ABILHAND-Kids was translated to Brazilian Portuguese and translated back by two certified translators in each phase. After the expert committee approval, the pre-test version was applied in 40 parents of children with cerebral palsy in order to verify item comprehension. Twenty-one volunteers were enrolled in the psychometric properties analysis. Reproducibility was verified by interrater and intrarater reliability and the validity was tested by investigating Box and Block Test, Purdue Pegboard Test and grip strength correlations. ABILHAND-Kids showed strong intrarater (ICC=0.91) and interrater (ICC=0.97) reliability and high internal consistency (Cronbach's alfa: 0.99). ABILHAND-Kids showed significant correlations with Box and Block Test (performed by dominant upper extremity), Purdue Pegboard Test and grip strength. The Brazilian Portuguese version of ABILHAND-Kids is a reliable tool to measure upper extremities function of children with cerebral palsy, based on the perception of their parents.
\end{abstract}

Keywords | Cerebral Palsy; Validation Studies; Evaluation.

RESUMO I O objetivo deste estudo foi traduzir o ABILHAND-Kids para o português brasileiro, adaptá-lo culturalmente e verificar sua validade e confiabilidade. O ABILHAND-Kids foi traduzido para o português e a tradução reversa foifeita por dois tradutoresindependentes em cada fase. Após a aprovação do comitê, a versão pré-teste foi aplicada em 40 voluntários com filhos com paralisia cerebral para verificar a compreensão dos itens. Participaram da análise das propriedades psicométricas 21 voluntários. A reprodutibilidade foi verificada por análise da confiabilidade intra e interavaliador e a validade pela correlação com o Box and Block Test, Purdue Pegboard Test e força de preensão manual. O ABILHAND-Kids demonstrou alta confiabilidade intra-avaliador $($ ICC=0,91) e interavaliador $(I C C=0,97)$ e alta consistência interna (Alfa de Cronbach: 0,99). O ABILHAND-Kids apresentou correlação significativa com Box and Block Test (realizado pelo membro superior dominante), com o Purdue Pegboard Test and a força de preensão. A versão brasileira do ABILHANDkids é válida e confiável para avaliar a função de membros superiores em crianças com Paralisia Cerebral, com base na percepção de seus pais.

Descritores | Paralisia Cerebral; Estudos de Validação; Avaliação.

RESUMEN | El objectivo de este estudio fue traducir el ABILHAND-Kids para el portugués brasileño, adaptar culturalmente y verificar su validez y confiabilidad. El ABILHAND-Kids fue traducido para el portugués y la traducción reversa fue hecha por dos traductores independientes en cada fase. Después de aprobación del comité, la versión pré-prueba fue aplicada en 40 voluntarios con hijos presentando parálisis cerebral para verificar la comprehensión de los ítems. Participaron del análisis de las propriedades psicométricas 21 voluntarios. La reproducibilidad fue verificada por análisis de confiabilidad intra y interevaluador y validez por

\footnotetext{
'Health Sciences Institute, Universidade Paulista - Sorocaba (SP), Brazil.

2Department of Physical Therapy, Universidade Federal de São Carlos - São Carlos (SP), Brazil.

${ }^{3}$ Faculdade de Ciências da Saúde, Universidade Metodista de Piracicaba - Piracicaba (SP), Brazil.

${ }^{4}$ Centro de Ciências da Saúde, Universidade do Sagrado Coração - Bauru (SP), Brazil.
} 
correlación con el Box and Block Test, el Purdue Pegboard Test y la fuerza de prensión manual. El ABILHAND-Kids demonstró alta confiabilidad intra $($ ICC $=0,91)$ y interevaluadora $($ ICC $=0,97)$, y alta consistencia interna (Alfa de Cronbach: 0.99). El ABILHANDKids presentó correlación significativa con el Box and Block Test (realizado por el miembro superior dominante), el Purdue
Pegboard Test y la fuerza de prensión. La versión brasileña del ABILHANDKids es válida y confiable para evaluar la función de miembros superiores en niños con parálisis cerebral basado en la percepción de sus padres.

Palabras clave I Parálisis Cerebral; Estudios de Validación; Evaluación.

\section{INTRODUCTION}

Non-progressive chronic encephalopathy, also known as cerebral palsy (CP), is one of the most common cause of children's disability and the prevalence rate is 2 to 5 cases per 1,000 born alive ${ }^{1,2}$. CP comprises a group of permanent movement and posture disorders, resulted from non-progressive disturbances that occurred in the developing fetal or infant brain ${ }^{3}$. These characteristics may result in changes in fine motor coordination and manual dexterity, which can limit manual ability and functionality ${ }^{1,2,4}$. Manual ability is defined as the capability of performing daily activities that require upper extremities. This ability can be influenced by the environment, auxiliary devices, personal aspects and motivational, emotional and cognitive states. Therefore, manual dexterity can be measured by the perception of parents on the performance of daily activities ${ }^{1,5,6}$.

A comprehensive analysis of impairments requires standardized tools to measure and follow clinical progression and to establish treatment effectiveness. Questionnaires and functional scales are important for clinical practice and scientific research to quantify outcomes in an effective, objective, reliable and inexpensive manner ${ }^{7,8}$. However, questionnaires developed in other languages must be translated and culturally adapted to the environment in which it will be applied. Psychometric properties must be evaluated to ensure that the test has the same characteristics, validity and reliability as the original version ${ }^{7,8}$.

ABILHAND-Kids questionnaire was developed to evaluate manual ability of children with $\mathrm{CP}$ based on the perception of their parents. Manual ability is required in daily activities involving upper limbs, in order to achieve the activity goal ${ }^{9}$. The strategies shown by children were rated in 21 items, according to the perception of their parents. No human or technical assistance was offered during the activities. Scoring is based on a three level scale: the activity is impossible, difficult or easy to complete 9 . The twenty-one topics in this scale were proved to be reliable and reproducible ${ }^{1}$. They were elaborated according to the Rasch measurement model to convert an ordinal scale to linear measurements of a unidimensional scale ${ }^{1,10}$.

The questionnaire was developed in French and has been used in several clinical studies. It is a useful tool for assessing the relationship between manual ability and dystonia and choreoathetosis ${ }^{11}$, for identifying factors that might influence children's manual function in long term ${ }^{12}$, and for identifying children's upper limb impairments ${ }^{13}$. Moreover, ABILHAND-Kids questionnaire has been used as an outcome measure in several interventional studies ${ }^{14-18}$ and in other clinical conditions such as radial deficiency ${ }^{19}$, obstetric brachial plexus injury ${ }^{20}$ and paediatric ischaemic stroke ${ }^{21}$.

ABILHAND-Kids has been translated to other languages, such as Turkish, English and Dutch ${ }^{9,22}$. However, the translation, transcultural equivalence and psychometric properties are not available in Brazil. The aim of the present study was to develop a transcultural version of ABILHAND-Kids and to evaluate its reliability and validity for parents of children with $\mathrm{CP}$ in Brazil.

\section{METHODOLOGY}

\section{Participants}

Sixty-one parents of children with CP took part in the study. Forty of them participated during the pretest phase and the remaining 21 took part during psychometric properties analysis. Volunteers were recruited by verbal and digital invitation. Participants were considered eligible for the study if they were 18 to 60 years old, if their children had been diagnosed with $\mathrm{CP}$ and were between six and 18 years old ${ }^{23}$. Children using bracing on upper extremities or with comprehension difficulties on simple verbal commands were excluded. 
The author of the original version consented to this study and originality was confirmed by e-mail. This study was approved by the Human Research Ethics Committee of the Universidade Paulista. Written consent clarifying the experimental protocol was signed by each volunteer.

\section{Procedures}

Translation, back-translation (translation back to the original language), committee analysis, pretest phase and validation were performed ${ }^{7,24}$ (Figure 1).
ABILHAND-Kids questionnaire was translated to Portuguese by two independent Brazilian translators, who are fluent in English (T1 and T2). These two versions were compared and discussed by the committee composed by four specialized physical therapists, and by two translators. When divergences occurred, alterations were performed to elaborate the consensual version in Portuguese (T12), to make sure that the translated version reflected the same item content in the original questionnaire.

T12 version was translated back to English by two independent English-native translators (BT1 and BT2), who did not have any knowledge about the original version.

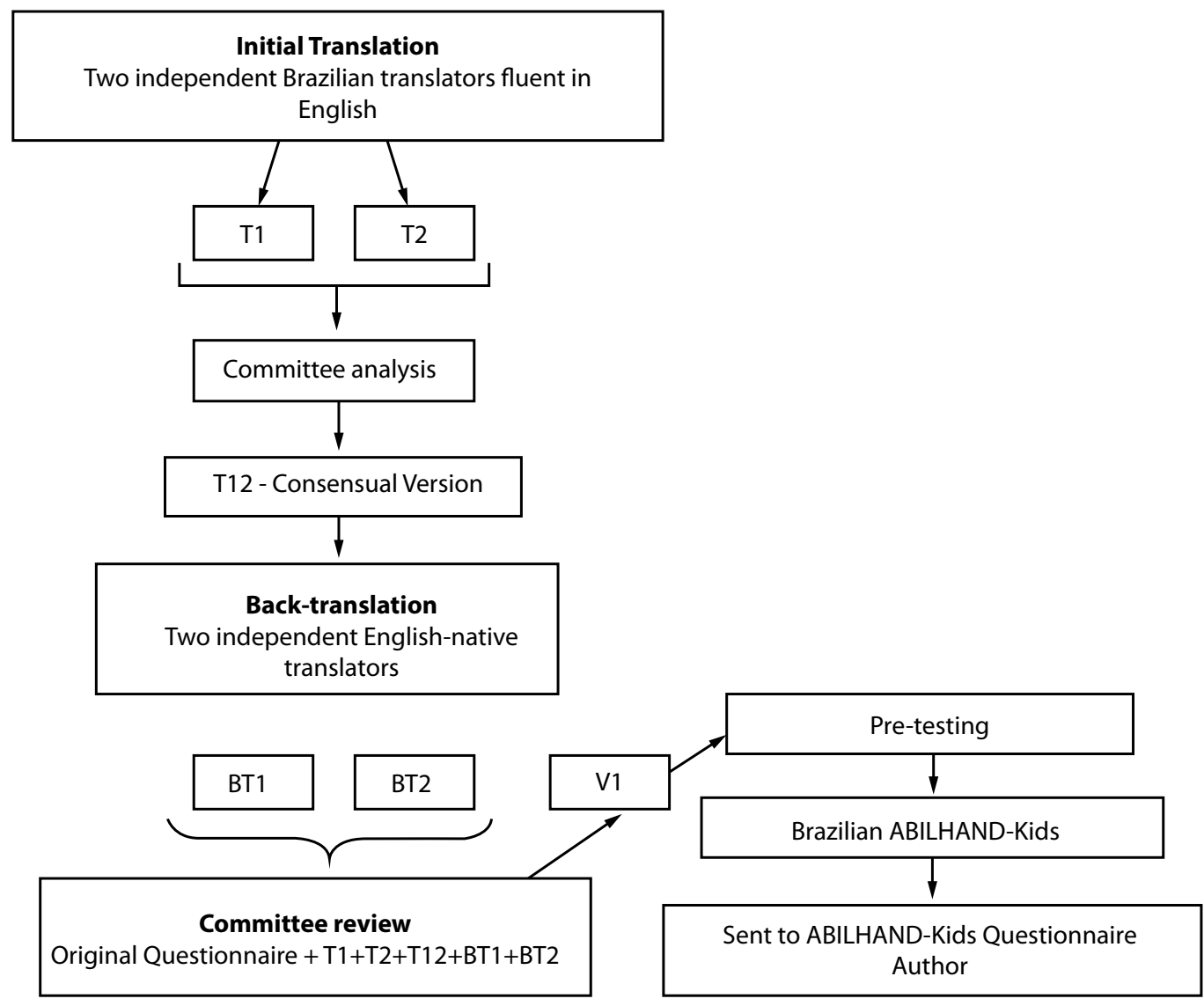

Figure 1. Study flow chart

Then, the committee held a further meeting and differences among the translations (T1, T2, T12, BT1, BT2) were analyzed in order to elaborate the first version (V1), which was used during pretest phase. Pretest phase was performed to analyze comprehension and acceptability of questions and answers ${ }^{8}$. After pretesting, the final version of ABILHAND-Kids was sent to the author of the original version for appreciation and approval (Graph 1).

\section{Reliability evaluation}

Interrater and intrarater reliability analysis were performed to evaluate reproducibility. ABILHAND-Kids was applied by two researchers, with a one-hour interval between tests (interraters). In a period of three to seven days, the first researcher applied the questionnaire again (intrarater). Internal consistency was evaluated to address the interrelation of different topics (topic homogeneity) 25 . 


\section{Validity evaluation}

Association among ABILHAND-Kids and other tests that measure motor function and muscle strength were evaluated ${ }^{25}$.

Box and Block Test (BBT) is a functional test of gross manual dexterity, which requires the patient to pick up and transfer blocks $(2.5 \mathrm{~cm})$ from one side to the other of a divided box for 60 seconds. Then, the number of transferred boxes was counted ${ }^{26}$.

The Purdue Pegboard Test (PPT) is a functional test of manual dexterity and bimanual coordination. Children with $\mathrm{CP}$ were instructed to insert one pin at a time in a board as quickly as possible in a fixed time. The number of inserted pins is the final score ${ }^{27,28}$. For the assembly test, $\mathrm{CP}$ children were asked to put together pins, washers and collars with both hands and the number of parts assembled was scored. The test compiles five separate scores from test procedures, including dominant hand (30 s), non-dominant hand (30 s), both hands (30 s), and assembly (60s) ${ }^{27,28}$.

Grip strength is a hand function evaluation and an indicator of general health. The mean of three maximum contractions of the dominant hand was recorded with Jamar hydraulic hand dynamometer ${ }^{29}$.

\section{Statistical analysis}

Data analysis was performed using SPSS for Windows (version 12.0, SPSS Inc.). Continuous variables are expressed as mean and standard deviation and the categories are shown as frequency and percentage.

Test-retest reliability was evaluated by intraclass correlation coefficient (ICC) with 95\% confidence intervals $(95 \% \mathrm{CI})$. Interrater and intrarater reliability was evaluated. Internal consistency was measured by Cronbach's alpha coefficient. Pearson correlation coefficient assessed the relationship between ABILHAND-Kids scores and BBT, PPT and grip strength scores.

\section{RESULTS}

During the translation phase, no grammar difficulties were reported, however, a few alterations were performed by the committee to achieve equivalence between the original and target version. Every item of T1 and T2 versions was discussed to elaborate $\mathrm{T} 12$ consensual version.
Experiential equivalence was observed in two items. On item 6, "Rolling up a sleeve of a sweater" was translated as "Puxar a manga para cima de uma blusa". The term "sweater" is rarely used among Brazilians, and the term "blusa" was chosen by the committee. On item 1, "Open a jar of jam", the movement performed to open the jar is evaluated, so "doce" was more adequate (more general than jam). No divergences were found on semantic or idiomatic equivalences (Chart 1 ).

In the second review, after back-translation, differences among all versions and the original questionnaire were analyzed by the committee. Minimal changes were made during this phase to elaborate the version used at the pretest phase. Few differences were found between BT1 and BT2. For example, one translator used the gerund of the verb ("opening") and the other translator preferred to use the imperative form ("open") at the beginning of the sentence. For V1 elaboration, the committee decided that the gerund form was more suitable for the questionnaire. Moreover, "unwrapping" and "unscrewing" were translated as "open" and then translated back to "opening". The term "opening" is frequently used among Brazilians for different actions that involves opening an object, thus, "opening" was maintained in V1.

Pretest was performed with 40 participants and all questionnaire topics showed at least $90 \%$ of comprehension, requiring no alterations. The versions were sent by e-mail to the author of the ABILHANDKids original version, who observed that topic 10 "Opening a breadbox" - was translated as "Abrir um pacote de pão". However, in Belgium (the questionnaire's place of origin), the word "breadbox" is referred to a sandwich-maker ("sanduicheira" in Portuguese) or lunch bag ("lancheira" in Portuguese). Therefore, topic 10 was modified to "Abrir uma Sanduicheira/Lancheira" to guarantee conceptual equivalence (Chart 1$)$.

Chart 1. Original ABILHAND-Kids and Brazilian version of ABILHAND-Kids

\begin{tabular}{ll}
\multicolumn{1}{c}{ Original Questionnaire } & \multicolumn{1}{c}{ Brazilian Version } \\
$\begin{array}{l}\text { 1. Opening a jar of jam } \\
\begin{array}{l}\text { 2. Putting on a backpack } \\
\text { schoolbag }\end{array}\end{array}$ & Abrir um pote de doce \\
$\begin{array}{l}\text { 3. Opening the cap of tooth- } \\
\text { paste tube }\end{array}$ & Abrir a tampa da pasta de dente \\
$\begin{array}{l}\text { 4. Unwrapping a chocolate bar } \\
\text { 5. Washing the upper-body }\end{array}$ & Abrir uma barra de chocolate \\
$\begin{array}{l}\text { 6. Rolling-up a sleeve of a } \\
\text { sweater }\end{array}$ & Lavar a parte de cima do corpo \\
& Puxar a manga para cima \\
&
\end{tabular}


Chart 1. Continuation

\begin{tabular}{ll}
\multicolumn{1}{c}{ Original Questionnaire } & \multicolumn{1}{c}{ Brazilian Version } \\
7. Sharpening a pencil & Apontar um lápis \\
8. Take off a T-shirt & Tirar uma camiseta \\
9. Squeezing toothpaste onto a & Colocar a pasta de dente na escova \\
toothbrush & Abrir uma lancheira (sanduicheira) \\
10. Opening a bread box & Abrir a tampa de uma garrafa \\
11. Unscrewing a bottle cap & Fechar o zíper das calças \\
12. Zipping-up trousers & Abotoar uma camisa/casaco \\
13. Buttoning up a shirt \sweater & Encher um copo com água \\
14. Filling a glass with water & Acender uma lâmpada (abajur) \\
15. Switching on a beside lamp & Colocar um chapéu (boné) \\
16. Putting on a hat & Apertar botões de uma jaqueta \\
17. Fastening the snap of a jacket & Abotoar as calças \\
18. Buttoning up trousers & Abrir um pacote de batatinha/ \\
19. Opening a bag of chips & salgadinho \\
20. Zipping-up a jacket & Fechar o zíper de uma jaqueta \\
21. Taking a coin of a pocket & Tirar uma moeda do bolso
\end{tabular}

Twenty-one parents participated in reliability analysis, validity and internal consistency phase, with no sample loss during the study's period. Participants were $43.7 \pm 11.8$ years old; 14 of them $(66 \%)$ were women; six (28\%) had not completed elementary school, ten (47\%) completed high school and only one (4.7\%) graduated from university (Table 1).

Table 1. Sample characteristics at reliability and validity phases

\begin{tabular}{lr}
\hline \multicolumn{1}{c}{ Variable } & Descriptive analysis \\
Gender $\mathbf{n}(\%)$ & \\
Male & $13(61.9)$ \\
Female & $8(38)$ \\
Age, mean \pm SD & $13.1 \pm 4.6$ \\
Dominancy $\mathbf{n}(\%)$ & \\
Right & $10(47.6)$ \\
Left & $11(52.3)$ \\
Cerebral palsy characteristics, $\mathbf{n}(\%)$ & \\
Quadriplegia/ paresis & $4(17.39)$ \\
Diplegia & $15(73.91)$ \\
Hemiplegia/ paresis & $4(8.69)$ \\
$\begin{array}{l}\text { Numeric data are shown in mean } \pm \text { standard deviation (SD) and categorical numbers in } \\
\text { frequency (\%) }\end{array}$
\end{tabular}

ABILHAND-Kids Brazilian version showed high intrarater and interrater reliability (Table 2). Cronbach's alpha was 0.99 and correlation between BrazilABILHAND-Kids, BBT (dominant upper limb), PPT and grip strength were significant (Table 3).

Table 2. Intrarater and interrater reliability analysis

\begin{tabular}{ccccc} 
& \multicolumn{2}{c}{ Intrarater reliability } & \multicolumn{2}{c}{ Interrater reliability } \\
\hline & ICC & $95 \% \mathrm{Cl}$ & ICC & $95 \% \mathrm{Cl}$ \\
ABILHAND-Kids & 0.91 & $0.88-0.98$ & 0.97 & $0.90-0.99$
\end{tabular}

ICC: intraclass correlation coefficient; Cl: confidence interval
Table 3. Correlation between ABILHAND-Kids, Grip Strength, Box and Blocks Test and Purdue pegboard Test

\begin{tabular}{lcc} 
& \multicolumn{2}{c}{ ABILHAND-Kids } \\
\hline \multicolumn{1}{c}{$r$} & $p$-value \\
Grip Strength & 0.431 & 0.05 \\
Box and Blocks Test & & \\
DH & 0.611 & 0.003 \\
NH & 0.334 & 0.139 \\
Purdue Pegboard Test & & \\
DH & 0.588 & 0.005 \\
ND & 0.594 & 0.005 \\
BH & 0.504 & 0.020 \\
Assembly & 0.572 & 0.007
\end{tabular}

DH: dominant hand; $\mathrm{NH}$ : non-dominant hand; $\mathrm{BH}$ : both hands

\section{DISCUSSION}

This study demonstrates that the Brazilian version of ABILHAND-Kids is reproducible and valid for measuring the perception of parents on the manual ability of their children with $\mathrm{CP}$. The questionnaire is suitable for health assistance and research studies.

Brazilian ABILHAND-Kids test-retest reliability at the first and the second assessment was 0.91 for intrarater ICC and 0.97 for interraters. The original ABILHAND-Kids test-retest reliability was also excellent $(r=0.91, p=0.001)^{1}$.

Several clinical tests can be used to assess hand function, such as BBT that measure gross manual dexterity, PPT that assess manual dexterity and bimanual coordination, and grip strength that is an indicator of general health. We assessed the association of ABILHAND-Kids Brazilian version with BBT, PPT, and grip strength. A significant association was observed between ABILHAND-Kids Brazilian version $(r=0.61, p=0.003)$ and the dominant hand results from BBT. However, no significant association was observed with the results obtained with nondominant hand $(r=0.33, p=0.139)$. These findings partially corroborate with the results reported in the original version, which showed significant association with dominant $(r=0.69, p<0.001)$ and non-dominant hand evaluation $(r=0.71, p<0.001)^{28}$. This difference between original and Brazilian versions might be due to the difference of volunteers' topography. In our sample, we included $17 \%$ of patients with quadriplegia, $73 \%$ with diplegia and $8 \%$ with hemiplegia. In the original version, $25 \%$ of patients were quadriplegic, $17 \%$ diplegic and $56 \%$ hemiplegic. 

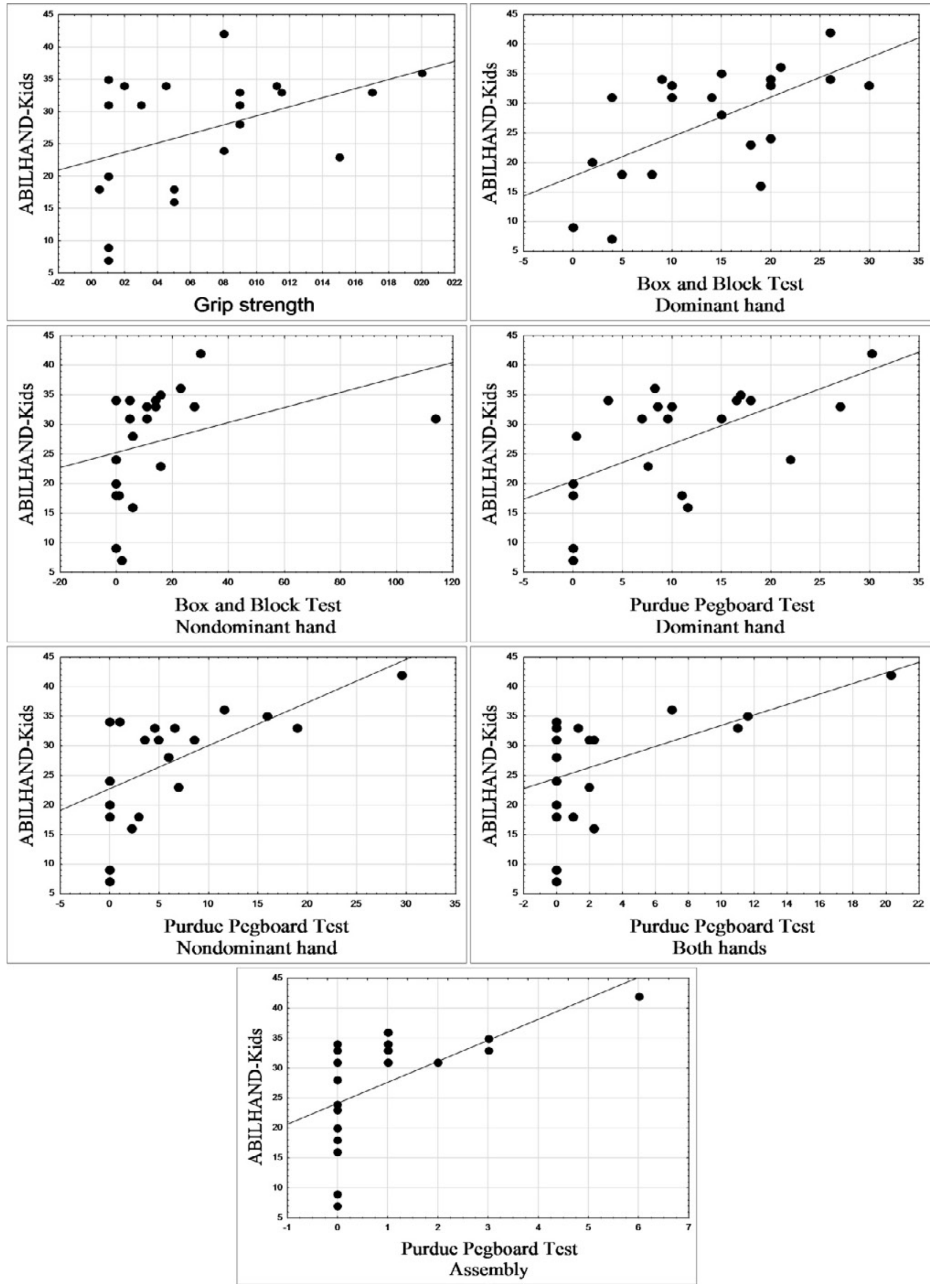
We observed a significant relationship between the Brazilian version of ABILHAND-Kids and PPT dominant hand $(r=0.58, p=0.005)$ and nondominant hand scores $(r=0.59, p=0.005)^{28}$. These findings corroborate results reported in the original version, which showed significant correlations with dominant $(r=0.68, p<0.001)$ and with non-dominant hands $(r=0.57, p=<0.001)$. The Brazilian version showed significant association with grip strength $(r=0.43$, $p=0.05)$, as did the original version $(r=0.48)$.

The Brazilian version showed an Internal Consistency of Cronbach's alpha of 0.99 . Instead of performing Cronbach's alpha to assess internal consistency, the original version used a person separation reliability coefficient that was determined as the ratio of the true to the observed (true + error) variance in the sample $(r=0.94)$.

The description of every phase of translation and cultural adaptation is important to provide enough information to help choosing proper evaluation tools for clinical and scientific purposes ${ }^{7,8}$. Otherwise, the results provided by the questionnaire might be biased, affecting clinical practice or scientific researches ${ }^{7}$. The translation and cross-cultural adaptation methods used in this study are well established in the literature ${ }^{7,24}$.

Several limitations of this study need to be addressed. Limited sample size could reduce statistical power of the analysis, and a responsiveness analysis of the Brazilian version is necessary. Further researches with larger sample size and diversified topography are needed to evaluate the responsiveness of the Brazilian version of ABILHANDKids. According to Elvrum et al. ${ }^{30}$, performance on abilities tests in clinical environment might differ from manual abilities performed during daily activities of children with $\mathrm{CP}$. Other questionnaires also evaluate upper extremities function based on the perception of parents (e.g., children's hand-use experience questionnaire, pediatric motor activity log and infant motor activity log) 9 and these tools could be applied in the validation process. However, these questionnaires have not been translated and culturally adapted to Brazilian Portuguese.

\section{CONCLUSION}

The Brazilian version of ABILHAND-Kids showed to be an evaluation tool of easy comprehension and application, valid and reliable to measure upper extremities function of children with cerebral palsy by their parents' perception in Brazil.

\section{REFERENCES}

1. Arnould C, Penta M, Renders A, Thonnard JL. ABILHANDKids: a measure of manual ability in children with cerebral palsy. Neurology. 2004;63(6):1045-52. doi: 10.1212/01. WNL.0000138423.77640.37.

2. Colver A, Fairhurst C, Pharoah POD. Cerebral palsy. Lancet. 2013;383(9924):1240-9. doi: 10.1016/S0140-6736(13)61835-8.

3. Rosenbaum P, Paneth N, Leviton A, Goldstein M, Bax M, Damiano D, et al. A report: the definition and classification of cerebral palsy. Dev Med Child Neurol Suppl. 2007;109:8-14.

4. Pruitt DW, Tsai T. Common medical comorbidities associated with cerebral palsy. Phys Med Rehabil Clin N Am. 2009;20(3):453-67. doi: 10.1016/j.pmr.2009.06.002.

5. Majnemer A, Shikako-Thomas K, Shevell M, Poulin C, Lach L, Law $M$, et al. The relationship between manual ability and ambulation in adolescents with cerebral palsy. Phys Occup Ther Pediatr. 2013;33(2):243-52. doi: 10.3109/01942638.2012.754394.

6. Carnahan KD, Arner M, Hägglund G. Association between gross motor function (GMFCS) and manual ability (MACS) in children with cerebral palsy. A population-based study of 359 children. BMC Musculoskelet Disord. 2007;8:50-7. doi: 10.1186/1471-2474-8-50.

7. Beaton DE, Bombardier C, Guillemin F, Ferraz MB. Guidelines for the process of cross-cultural adaptation of self-report measures. Spine. 2000;25(24):3186-91.

8. Wild D, Grove A, Martin M, Eremenco S, McElroy S, VerjeeLorenz A, et al. Principles of good practice for the translation and cultural adaptation process for Patient-Reported Outcomes (PRO) measures. Value Health. 2005;8(2):94-104. doi: 10.1111/j.1524-4733.2005.04054

9. Wallen M, Stewart K. Upper limb function in everyday life of children with cerebral palsy: description and review of parent report measures. Disabil Rehabil. 2015;37(15):1353-61. doi: 10.3109/09638288.2014.963704.

10. Wagner LV, Davids JR. Assessment tools and classification systems used for the upper extremity in children with cerebral palsy. Clin Orthop Relat Res. 2012;470(5):1257-71. doi: 10.1007/s11999-011-2065-X.

11. Monbaliu E, de Cock P, Ortibus E, Heyrman L, Klingels K, Feys $H$. Clinical patterns of dystonia and choreoathetosis in participants with dyskinetic cerebral palsy. Dev Med Child Neurol. 2016;58(2):138-44. doi: 10.1111/dmcn.12846.

12. Klingels $K$, Feys $H$, De Wit L, Jaspers $E$, Van de Winckel A, Verbeke $G$, et al. Arm and hand function in children with unilateral cerebral palsy: a one-year follow-up study. Eur J Paediatr Neurol. 2012;16(3):257-65. doi: 10.1016/j. ejpn.2011.08.001.

13. Klingels K, Demeyere I, Jaspers E, De Cock P, Molenaers G, Boyd R, et al. Upper limb impairments and their impact on activity measures in children with unilateral cerebral palsy. Eur J Paediatr Neurol. 2012;16(5):475-84. doi: 10.1016/j. ejpn.2011.12.008.

14. Yildizgören MT, Nakipoğlu Yüzer GF, Ekiz T, Özgirgin N. Effects of neuromuscular electrical stimulation on the wrist and finger flexor spasticity and hand functions in cerebral 
palsy. Pediatr Neurol. 2014;51(3):360-4. doi: 10.1016/j. pediatrneurol.2014.05.009.

15. Geerdink Y, Aarts P, van der Burg J, Steenbergen B, Geurts A. Intensive upper limb intervention with selfmanagement training is feasible and promising for older children and adolescents with unilateral cerebral palsy. Res Dev Disabil. 2015;43-44:97-105. doi:10.1016/j.ridd.2015.06.013.

16. Acar G, Altun GP, Yurdalan S, Polat MG. Efficacy of neurodevelopmental treatment combined with the Nintendo Wii in patients with cerebral palsy. J Phys Ther Sci. 2016;28(3):774-80. doi: 10.1589/jpts.28.774.

17. Bruchez R, Jequier Gygax M, Roches S, Fluss J, Jacquier D, Ballabeni P, et al. Mirror therapy in children with hemiparesis: a randomized observer-blinded trial. Dev Med Child Neurol. 2016;58(9):970-8. doi: 10.1111/dmcn.13117.

18. Speth L, Janssen-Potten $Y$, Leffers $P$, Rameckers $E$, Defesche A, Winkens B, et al. Effects of botulinum toxin A and/or bimanual task-oriented therapy on upper extremity impairments in unilateral cerebral palsy: an explorative study. Eur J Paediatr Neurol. 2015;19(3):337-48. doi: 10.1016/j. ejpn.2015.01.004.

19. Buffart LM, Roebroeck ME, Janssen WG, Hoekstra A, Hovius SE, Stam HJ. Comparison of instruments to assess hand function in children with radius deficiencies. J Hand Surg Am. 2007;32(4):531-40. doi: 10.1016/j.jhsa.2007.01.011.

20. Spaargaren E, Ahmed J, van Ouwerkerk WJ, de Groot V, Beckerman $\mathrm{H}$. Aspects of activities and participation of 7-8 year-old children with an obstetric brachial plexus injury. Eur J Paediatr Neurol. 2011;15(4):345-52. doi: 10.1016/j. ejpn.2011.03.008.

21. Kornfeld S, Studer M, Winkelbeiner S, Regenyi $M$, Boltshauser E, Steinlin M. Quality of life after paediatric ischaemic stroke. Dev Med Child Neurol. 2017;59(1):45-51. doi: 10.1111/dmcn.13295.

22. Oksuz C, Kilinc M, Alemdaroglu Ý, Karahan S, Demirhan HA, Yilmaz OT, et al. Rasch measurement model to investigate the Turkish version of Abilhand-kids questionnaire in neuromuscular disease. Neuromuscul Disord. 2013;23(910):789-90. doi: 10.1016/j.nmd.2013.06.532.

23. Almeida KM, Albuquerque KA, Ferreira ML, Aguiar SKB, Mancini MC. Reliability of the brazilian portuguese version of the gross motor function measure in children with cerebral palsy. Braz J Phys Ther. 2016;20(1):73-80. doi: 10.1590/ bjpt-rbf.2014.0131.

24. Guillemin F, Bombardier C, Beaton D. Cross-cultural adaptation of health-related quality of life measures: literature review and proposed guidelines. J Clin Epidemiol. 1993;46(12):1417-32. doi: 10.1016/0895-4356(93)90142-N.

25. Terwee CB, Bot SDM, de Boer MR, van der Windt DAWM, Knol DL, Dekker J, et al. Quality criteria were proposed for measurement properties of health status questionnaires. J Clin Epidemiol. 2007;60(1):34-42. doi: 10.1016/j. jclinepi.2006.03.012.

26. Connell LA, Tyson SF. Clinical reality of measuring upperlimb ability in neurologic conditions: a systematic review. Arch Phys Med Rehabil. 2012;93(2):221-8. doi: 10.1016/j. apmr.2011.09.015.

27. Buddenberg LA, Davis C. Test-retest reliability of the purdue pegboard test. Am J Occup Ther. 2000;54(5):555-8. doi:10.5014/ajot.54.5.555.

28. Arnould C, Bleyenheuft Y, Thonnard JL. Hand functioning in children with cerebral palsy. Front Neurol. 2014;5(48):1-10. doi: 10.3389/fneur.2014.00048.

29. Ploegmakers JJ, Hepping AM, Geertzen JH, Bulstra SK, Stevens M. Grip strength is strongly associated with height, weight and gender in childhood: a cross sectional study of 2241 children and adolescents providing reference values. J Physiother. 2013;59(4):255-61. doi: 10.1016/ S1836-9553(13)70202-9.

30. Elvrum AK, Saether R, Riphagen, II, Vik T. Outcome measures evaluating hand function in children with bilateral cerebral palsy: a systematic review. Dev Med Child Neurol. 2016:58(7):662-71. doi: 10.1111/dmcn.13119. 